\title{
Self-Defence in Legislation of Christian Emperors
}

Self-defence understood as repelling an unlawful attack on a legally protected interest seems to be present in every legislation of the European cultural circle. This also applies to antiquity, including ancient Rome. The source texts show that in the Roman legal order there were cases of crimes going unpunished in result of having recognised the lack of unlawfulness of an act. This scheme embraces the notion of self-defence.

The existence of the beginnings of self-defence treated as a circumstance excluding the unlawfulness of an act may be seen in the provisions of the Law of the Twelve Tables, allowing the killing of a night thief, and, after summoning witnesses, also a daylight thief who defended themselves with a weapon. ${ }^{1}$ Thus under certain circumstances a robber could be killed. It may therefore be assumed that it was even more possible to chase away, beat or imprison a thief, using any necessary means. During the pre-classical law period that permission began to be gradually extended. Over time, regulations emerged regarding protection against attempt-

\footnotetext{
* Dr. habil., Assistant Professor, the Cardinal Stefan Wyszyński University in Warsaw; e-mail: e.loska@uksw.edu.pl, ORCID ID: 0000-0001-6838-7721.

1 Cf. e.g. P. Solazzi, Furto di notte e desuetudine della legge, in: idem, Scritti di diritto romano, vol. 3, Napoli 1960, pp. 400 ff.; C. Gioffredi, I principi del diritto penale romano, Torino 1970, p. 92; A. Corbino, "Si nox furtum faxsit, si im occidit, iure caesus esto", in: Il problemo della pena criminale tra filosofia greca e diritto romano, ed. O. Diliberto, Napoli 1993, passim; L. Gagliardi, "Iure caesus esto", Labeo 1999, vol. 45, pp. 425 ff.; K. Amielańczyk, Rzymskie prawo karne w reskryptach cesarza Hadriana, Lublin 2006, pp. 84 ff.; idem, "Vim vi repellere licet". Kilka uwag na temat genezy prawa do obrony koniecznej w prawie rzymskim, Palestra 2008, vol. 53, no. 11/12, pp. 114 ff.; E. Loska, Zagadnienie obrony koniecznej w rzymskim prawie karnym, Warszawa 2011, pp. $21 \mathrm{ff}$.
} 
ed murder, personal injury or even bodily integrity. The starting point for the jurists' considerations were often the above-mentioned regulations of the Law of the Twelve Tables.

Over the centuries, this institution had undergone transformation, and already the classic jurisprudence based on the Law of the Twelve Tables decided that it was better to capture than to kill an attacker who did not pose a threat to the life or health of an attacked person. ${ }^{2}$

The rescript of Emperor Hadrian, the content of which can be found in the Digest (D. $48,8,1,4$ ), introduced the possibility of self-defence against rape. ${ }^{3}$ The emperor decided that a person who killed during a sexual assault on oneself or relatives should be released. However, it is not possible to determine whether it was a new regulation or confirmation of an existing practice. For example, it is not known whether Hadrian's regulation generally concerned the admission of self-defence against rape, or if it encompassed the existing possibility of repelling an attack on oneself by allowing actions to defend others. ${ }^{4}$ Justinian extended this regulation to the case of repelling rape on a woman devoted to religious service:

C. 1,3,53, pr.-1 (Imperator Justinianus): Raptores virginum vel viduarum vel diaconissarum, quae deo fuerint dedicatae, pessima criminum peccantes capitis supplicio plectendos fuisse decernimus, quod non solum ad iniuriam hominum, sed ad ipsius omnipotentis dei inreverentiam committitur. 1. Qui itaque huiusmodi crimen commiserint et qui eis auxilium tempore invasionis praebuerint, ubi inventi fuerint in ipsa rapina et adhuc flagrante crimine comprehensi a parentibus sanctimonialium virginum vel viduarum vel diaconissarum aut earum consanguineis vel tutoribus seu curatoribus, convicti interficiantur. "Iust. A. Hermogeni mag. off.* <a 533 XV k. Dec. Constantinopoli Iustiniano pp. A. III cons.>

It is worth noting that the source is not unambiguous, as the word raptus can mean both raping and kidnapping a woman for various purposes:

2 Coll. 7,3,3; D. 9,2,5 pr.; P. Solazzi, Furto di notte..., p. 400; E. Loska, Zagadnienie obrony koniecznej..., pp. $48 \mathrm{ff}$.

3 On this imperial constitution see, among others, K. Amielańczyk, Czy kontratyp obrony koniecznej ma rzymska tradycje? W poszukiwaniu przestanek dopuszczalności prawa do samoobrony w rzymskim prawie karnym, in: "Quid leges sine moribus?” Studia nad prawem rzymskim dedykowane Profesorowi Markowi Kuryłowiczowi w 65. rocznice urodzin oraz 40-lecie pracy naukowej, ed. K. Amielańczyk, Lublin 2009, pp. 65 ff.

4 K. Amielańczyk, Twórcza interpretacja "legis Corneliae de sicariis et veneficis" przez Hadriana i jurysprudencję cesarska, Studia Prawnoustrojowe 2007, no. 7, pp. 37 ff. 
sexual but also matrimonial ones. Especially the latter could happen with the consent of a woman, but according to the further text of the constitution it did not matter. Perhaps also because of the fact that women devoted to God could no longer decide their own fate.

Justinian described this case as the worst type of crime because the one who commits it acts not only against humanity but also against God. The criminal was punished with death. If he was caught in the act, the parents, relatives, kins or guardians of the woman had the right to kill not only the attacker (a rapist or kidnapper) but also those who helped him. It seems that the word convinco used in this fragment of the constitution should be understood as repelling the assault and not indicating the need to prove a criminal offence. Otherwise there would have been no need to distinguish the situation of capturing an offender in flagrante since the punishment specified in the principium of the constitution was to be death. This meant that as soon as the attack was thwarted, the woman's relatives had the right to kill the attacker in order to definitively repel the assault.

An almost identical and equally justified solution is provided in another fragment of the same constitution contained in C. 9,13,1 regarding the regulation of raptores virginorum honestarum vel ingenuarum, even if the girl was not devoted to religious service. ${ }^{5}$

The constitution which allowed citizens to defend themselves against emboldened soldiers, deserters and other robbers is considered the most important post-classical extension of self-defence. The fragments of the relevant constitutions were contained in Justinian Code under the title Quando liceat sine iudice unicuique vindicare se vel publicam devotionem (When anyone

5 On the phenomenon of kidnapping women cf. B. Sitek, Raptores virginum vel viduarum vel diaconissarum. Studio sul rapimento delle donne votate a Dio nelle costituzioni degli imperatori romani [online], Diritto@Storia. Rivista Internazionale di Scienze Giuridiche e Tradizione Romana 2006, no. 5, http://www.dirittoestoria.it/5/Tradizione-Romana/ Sitek-Raptores-virginum.htm [access: 29.06.2020]; J. Wiewiorowski, Porywanie kobiet jako zjawisko społeczne w późnym antyku. Moralność a prawo, in: Homo, qui sentit. Ból i przyjemność w średniowiecznej kulturze Wschodu i Zachodu, ed. J. Banaszkiewicz, K. Ilski, Poznań 2013, pp. 197-219; cf. also idem, Odpowiedzialność senatora, który uprowadził dziewice (panne) - uwagi na marginesie CTh 9.1.1. = C 3.24.1, in: Contra leges et bonos mores. Przestęstwa obyczajowe w starożytnej Grecji i Rzymie, ed. H. Kowalski, M. Kuryłowicz, Lublin 2005, pp. 371 ff.; N.L. Nguyen, Roman Rape: An Overview of Roman Rape Laws from the Republican Period to Justinian's Reign, Michigan Journal of Gender and Law 2006, vol. 13, no. 1, pp. 14 ff. 
is allowed to avenge oneself or public order without the participation of a judge):

C. 3,27,1 pr. ${ }^{6}$ (Imperatores Valentinianus Theodosius et Arcadius AAA. ad provinciales): Liberam resistendi cunctis tribuimus facultatem, ut quicumque militum vel privatorum ad agros nocturnus populator intraverit aut itinera frequentata insidiis adgressionis obsederit, permissa cuicumque licentia dignus ilico supplicio subiugetur ac mortem quam minabatur excipiat et id quod intendebat incurrat. Melius enim est occurrere in tempore, quam post exitum vindicare. 1 . Vestram igitur vobis permittimus ultionem et, quod serum est punire iudicio, subiugamus edicto: nullus parcat militi, cui obviare telo oporteat ut latroni. <A. 391 d. k. Iul. Tatiano et Symmacho conss.>

Emperors Valentinian, Theodosius and Arcadius allowed all the inhabitants of the province to resist freely when anyone, be it a soldier or an individual, were to break into their premises at night. They could do the same to a bandit waiting on a busy road. The action was aimed at punishing the perpetrator, and more specifically turning the assault against the perpetrator. The reason for this decision was the desire to allow defence in a potentially dangerous situation when the attack took place at night or was an ambush. Defence which was to both thwart and punish the aggressor. And which could end in death. As the constitution states, it is better to resist in time than punish after the fact. Those words emphasise the essence of the institution of self-defence: this is the reaction (sometimes the only possible) to thwart an unlawful attack. And as such it should be allowed by law.

The next words specify that the edict is to be used in a situation when someone avenged harm done and it is too late to punish the perpetrator in court. In the further part, the emperors clearly allow to kill a soldier ("let no one spare him") if a soldier became a robber and the armed attack had to be repelled.

Before it was included in the Code of Justinian, this constitution had also been included in Theodosian Code (C. Th. 9,14,2). The following commentary can also be found in the preserved text of the Code:

6 = C. Th. 9,14,2. Cf. also a commentary to this fragment by the compilers of Theodosian Code: Quoties ad faciendam rapinam aliquis aut iter agentem aut domum cuiuslibet nocturnus exspoliator aggreditur, huius modi personis, quae vim sustinent, damus etiam cum armis licentiam resistendi, et si pro temeritate sua occisus fuerit ille, qui venerit, mors latronis ipsius a nemine requiratur. 
Interpretatio ${ }^{7}$ Q Quoties ad faciendam rapinam aliquis aut iter agentem aut domum cuiuslibet nocturnus exspoliator aggreditur, huius modi personis, quae vim sustinent, damus etiam cum armis licentiam resistendi, et si pro temeritate sua occisus fuerit ille, qui venerit, mors latronis ipsius a nemine requiratur.

Already after the constitution had been issued, the edict's words about a person attacking at night were clarified. Defence against robbery was always allowed in such a case. Everyone who was attacked (or more precisely: the person who endured/resisted violence), whether travelling or while being at home, had the right to resist with the use of the weapon. And if the brash attacker was killed, this death would not be investigated. It clearly follows that the one who would kill the assailant would stay unpunished.

Krzysztof Amielańczyk ${ }^{8}$ agrees with György Diösdi ${ }^{9}$ and thinks it is more appropriate to translate the term "miles" as a "deserter". In the imperial constitutions, however, the term "desertor" is used for describing soldiers who escaped from the army, so it seems that in such a case the term "miles" should not be narrowed. Arcadius and Theodosius were also co-authors of the constitution preserved in the fragment C. 3,27,2, discussed below, in which the word "desertor" is used, so it is clear that the emperors distinguished a deserter from a soldier in their legislative texts. Clyde Pharr, ${ }^{10}$ a translator of Theodosian Code, translates the opposition milites vel privati as "soldiers and non-soldiers" and emphasises that there were frequent cases when a soldier became a robber. In Theodosian Code, a title (C. Th. 7,1), that is devoted to soldiers, is different from that dedicated to deserters (C. Th. 7,18). The consistency in using the term "desertor"

7 On what interpretation was cf. F. Wieacker, Lateinische Kommentare zum Codex Theodosianus, in: Symbolae Friburgensis in honorem Ottonis Lenel, Leipzig 1931, pp. 259-356; J.F. Matthews, Interpreting the Interpretationes of the Breviarium, in: Law, Society, and Authority in Late Antiquity, ed. R.W. Mathisen, Oxford 2001, pp. 11-32; A. Adamo, Interpretazioni criminali al "Codex Theodosianus", Index. International Survey of Roman Law 2016, vol. 44, pp. 371-402.

8 K. Amielańczyk, Czy kontratyp..., p. 68, footnote 56.

9 G. Diösdi, "Vim vi repellere licet". A Contribution to the Study of the Question of Self-Defence in Roman Law, Acta Universitatis Wratislaviensis 1963, vol. 11, no. 1. Antiquitas, p. 193.

10 The Theodosian Code and Novels, and the Sirmondian Constitutions. A Translation with Commentary, Glossary, and Bibliography by Clyde Pharr in Collaboration with Theresa Sherrer Davidson and Mary Brown Pharr, with an Introduction by C. Dickerman Williams, Princeton 1952 (reprint New Jersey 2001)N p. 236. 
to describe a deserter is also clearly visible. Abel H.J. Greenidge ${ }^{11}$ made an interesting observation: he stated that the military oath changed the acts of latrocinium into legitima militia. Although this would mean that soldiers' actions were not allowed to be defended against, yet it appears that this was not the purpose of the constitution. The attacked person should not have an obligation to wonder whether the individual infringing their premises was an active soldier, or whether he had just deserted from the army. In this context, it seems more correct not to narrow the meaning of the word "miles" because it would mean that one might resist deserters but not soldiers. The narrowing interpretation does not seem right here.

Twelve years later, emperors said the following words on defence against deserters:

C. 3,27,2 (Imperatores Arcadius, Honorius, Theodosius AAA. Hadriano pp.): Opprimendorum desertorum facultatem provincialibus iure permittimus. Qui si resistere ausi fuerint, in his velox ubicumque iubermus esse supplicium. Cuncti etenim adversus latrones publicos desertoresque militiae ius sibi sciant pro quiete communi exercendae publicae ultionis indultum. <a $403 \mathrm{~d}$. VI non. Oct. Theodosio A. et Rumorido conss.>

Emperors Arcadius, Honorius and Theodosius gave the inhabitants of the province the right to capture (and perhaps even kill) deserters. The latter was certainly acceptable solution if captives resisted; the constitution spoke of an immediate punishment that could be imposed on them. It was in the public interest (or more precisely, to preserve public order) for the inhabitants of the province to possess the right to impose a public penalty on robbers and deserters.

The imperial constitution sanctioned cases in which an individual was allowed to resist strength by force (or even violence). This was to help public authorities. There were circumstances in which an immediate response to the criminal's action was necessary to avoid damage. And this immediate reaction had to take place on the part of a private person; the intervention of officials or services authorised to do so could not be sufficient, mainly because it would arrive too late. There could be no question of unlawfulness, when defence was a necessary reaction to protect one's own legal sphere. ${ }^{12}$

11 A.H.J. Greenidge, Roman Public Life, London 1901, p. 154.

12 G. Longo, Sulla legittima difesa e sullo stato di necessità in diritto romano, in: Sein und Werden im Recht. Festgabe für Ulrich von Lübtow zum 70. Geburtstag am 21. August 1970, ed. W.G. Becker, L. Schnorr, Berlin 1970, p. 329. 
The constitution preserved in C. $12,45,2$ was also devoted to defence against deserters:

C. 12,45,2 (Imperatores Arcadius, Honorius, Theodosius): Si desertores inventi resistendum atque armis obtinendum putaverint, tamquam rebelles in ipsis temeritatis suae conatibus opprimantur: ita tamen, ut provinciarum iudices sollicita cautione disquirant, ne sub falsarum tractoriarum nomine desertionis suae crimen defendere moliantur, nec suppositis aut commentis epistulis evadendi habeant facultatem. *Arcad. Honor. et Theodos. AAA. Hadriano pp. * <a 403 D. VI k. Mart. Ravennae Theodosio A. et Rumorido conss.>

Replying to Hadrian, the praetorian prefect, emperors Arcadius, Honorius and Theodosius emphasised that a "detected" deserter who resisted and used weapons for that purpose should be immediately (while trying to escape) killed as a rebel. The following part of the constitution warning against plotting to justify desertion relates to those who were captured (probably just surrendered).

What was the extension of the institution of self-defence in those constitutions? In the regulations of Christian emperors, for the first time a clear indication of a category or groups of people of "higher risk" was visible, those whose attacked and even the announcement of an attack could be repelled in all circumstances. In those cases, it was not necessary to repel the attack to legally use force. It was possible to act preventively even before the assault took place. The emperors pointed out that a "dangerous element" could be killed with impunity if it happened to be within a private property or on a busy road. It was as if using self-defence to thwart the high probability of an attack. The constitution referred to publica ultio (public revenge or punishment), which in that case meant that members of society could perform necessary defence; at the same time, they defended themselves against the attack and punished the perpetrator. Citizens obtained that right perhaps because the state could not cope with the problem alone. ${ }^{13}$

Who were those latrones, ${ }^{14}$ whose attack could be repelled before it even began? This follows indirectly from the constitution of emperor Gallienus contained in Justinian Code:

13 G. Diösdi, "Vim vi repellere licet"..., p. 193.

14 On latrones see first of all B.D. Shaw, Il bandito, in: L'uomo romano, ed. A. Giardina, Roma-Bari 1989, pp. 335-384; T. Grünewald, Räuber, Rebellen, Rivalen und Rächer. Studien zu 
C. 9,16,3 (Imperator Gallienus A. Munatio): Si, ut adlegas, latrocinantem peremisti, dubium non est eum, qui inferendae caedis voluntate praecesserat, iure caesum videri. <A. 265 PP. XIII k. Febr. Valeriano et Lucillo conss.>

One can deduce what was considered latrociunium from the rescript addressed to Munatius: it was a robbery, the perpetrator of which admitted bloodshed; they had an intention to kill. In that case, the emperor answered, they could be killed. The lawfulness of the manslaughter resulted from the fact that an attacked person was allowed to presume the existence of a life threat. ${ }^{15}$ The words of the rescript clearly testify to that - one who seems to be killed in accordance with law is one who first demonstrated the will to commit a murder.

Defence against villains was not only necessary, it was a must. Especially when public authorities did not cope with the problem of robberies. Regulations therefore went quite far. Robbers and rogues were not only allowed to be killed on the spot. They were not allowed to be sheltered, and if anyone did, they were punished for that. In turn, a captured villain had to be taken to court immediately. Emperors Gratian, Valentinian and Theodosius clearly stated that in the constitution addressed to the praetorian prefect:

C. Th. 9,29,2 (Imperatores Gratianus, Valentinianus et Theodosius AAA. ad Flavianum pf. p. post alia): "latrones" quisquis sciens susceperit vel offerre iudiciis supersederit, supplicio corporali aut dispendio facultatum pro qualitate personae et iudicis aestimatione plectatur. Si vero actor sive procurator latronem domino ignorante occultaverit et iudici offerre neglexerit, flammis ultricibus concremetur. $<391>$ *dat. III kal. Mart. Merobaude II et Saturnino coss. *

Whoever would knowingly hide bandits or neglect to bring them to justice was subject to corporal punishment or confiscation of property, depending on the social status and a judge's verdict. If a supervisor or property administrator (most likely a slave) hid a villain without an owner's knowledge and failed to hand a villain over to a judge, they were to be burnt alive.

\footnotetext{
"Latrones" im Römischen Reich, Stuttgart 1999 = idem, Bandits in the Roman Empire. Myth and Reality, London-New York 2004, passim; A. Bottiglieri, Latrocinia, Iura. Rivista Internazionale di Diritto Romano e Antico 2017, vol. 65, pp. 450-469, on the Theodosian Code, pp. $465 \mathrm{ff}$.

15 B. Cohen, Self-Help in Jewish and Roman Law, Revue Internationale des Droits de l'Antiquité 1955, no. 2, p. 112.
} 
Interpretatio. Si quis sciens in domo sua latronem susceperit aut eum occultare voluerit aut eum iudici tradere fortasse neglexerit, si ingenua et vilior persona est, fustigetur: si vero melior, damno ad arbitrium iudicis feriatur. Si vero actor aut procurator inscio domino hoc fecerit, incendio concremetur.

The interpretation lists three types of offences that were punished in accordance with that constitution: hiding a bandit, willingness to hide and neglecting to hand a bandit over to the justice. That is an extension to the original content. It can therefore be assumed that the problem was increasing. The punishment depended on the social position of a person hiding a thief. It could be a corporal punishment, confiscation of a part of the property and even a punishment of being burnt alive.

Ordinary citizens were punished for helping robbers, ${ }^{16}$ perhaps treated as complicity in their criminal offences. Hiding latrones was not in the interest of a community, and those delaying handing robbers over to justice were also treated as those who were hiding them.

A similar constitution of the same emperors was also found in Justinian Code, and this time it related to deserters:

C. 12,45,1 (Imperatores Gratianus, Valentinianus, Theodosius): Si quis forte desertorem agro tectoque susceperit atque apud se diu passus fuerit delitescere, actor quidem vel procurator loci, qui hoc sciens prudensque commiserit, capitali supplicio subiugetur, dominus vero, si huius rei conscius fuerit, praedii, in quo latuerit desertor, amissione puniatur. * Grat. Valentin. et Theodos. AAA. ad Syagrium pp. * <a 380 pp. Id. Iul. Romae Gratiano V et Theodosio AA. conss.>

Here it is clearly indicated that the part of property on which a deserter was hiding should be confiscated if the owner of the property knew about it. The punishment for a supervisor or property administrator who knowingly (sciens prudensque) hid or allowed a deserter to hide was death.

It is not easy to say whether the changes resulted from the religious beliefs of the emperors, or rather from the natural development of institutions in the still developing empire. The regulations on self-defence were scattered in various titles of the Code. This would indicate that those could still be casuistic solutions. Public authorities were unable to provide citizens with adequate protection against assaults and therefore a part of punishing competence was passed to the hands of citizens. They could

16 B.D. Shaw, Bandits in the Roman Empire, in: Studies in Ancient Greek and Roman Society, ed. R. Osborne, Cambridge 2004, p. 358. 
repel the attack with impunity even if it ended with the death of an attacker. However, this only applied to certain categories of assailants in specific places. One could always kill a deserter or anyone stealing at night on somebody else's premises as well as a villain who was prowling on a public road or intended to murder.

\section{Bibliography}

Adamo A., Interpretazioni criminali al "Codex Theodosianus", Index. International Survey of Roman Law 2016, vol. 44.

Amielańczyk K., Czy kontratyp obrony koniecznej ma rzymska tradycję? W poszukiwaniu przesłanek dopuszczalności prawa do samoobrony w rzymskim prawie karnym, in: "Quid leges sine moribus?" Studia nad prawem rzymskim dedykowane Profesorowi Markowi Kuryłowiczowi w 65. rocznice urodzin oraz 40-lecie pracy naukowej, ed. K. Amielańczyk, Lublin 2009.

Amielańczyk K., Rzymskie prawo karne w reskryptach cesarza Hadriana, Lublin 2006.

Amielańczyk K., Twórcza interpretacja "legis Corneliae de sicariis et veneficis" przez Hadriana i jurysprudencje cesarska, Studia Prawnoustrojowe 2007, no. 7.

Amielańczyk K., "Vim vi repellere licet". Kilka uwag na temat genezy prawa do obrony koniecznej w prawie rzymskim, Palestra 2008, vol. 53, no. 11/12.

Bottiglieri A., Latrocinia, Iura. Rivista Internazionale di Diritto Romano e Antico 2017, vol. 65.

Cohen B., Self-Help in Jewish and Roman Law, Revue Internationale des Droits de l'Antiquité 1955, no. 2.

Diösdi G., "Vim vi repellere licet". A Contribution to the Study of the Question of Self-Defence in Roman Law, Acta Universitatis Wratislaviensis 1963, vol. 11, no. 1. Antiquitas.

Gagliardi L., "Iure caesus esto", Labeo 1999, vol. 45.

Gioffredi C., I principi del diritto penale romano, Torino 1970.

Greenidge A.H.J., Roman Public Life, London 1901.

Grünewald T., Räuber, Rebellen, Rivalen und Rächer. Studien zu "Latrones" im Römischen Reich, Stuttgart 1999 = idem, Bandits in the Roman Empire. Myth and Reality, London-New York 2004.

Longo G., Sulla legittima difesa e sullo stato di necessità in diritto romano, in: Sein und Werden im Recht. Festgabe für Ulrich von Lübtow zum 70. Geburtstag am 21. August 1970, ed. W.G. Becker, L. Schnorr von Carolsfeld, Berlin 1970.

Loska E., Zagadnienie obrony koniecznej w rzymskim prawie karnym, Warszawa 2011.

Marzo S. di, Storia della procedura criminale romana. La giurisdizione dalle origini alle XII Tavole, Palermo 1898 (reprint Napoli 1986). 
Matthews J.F., Interpreting the Interpretationes of the Breviarium, in: Law, Society, and Authority in Late Antiquity, ed. R.W. Mathisen, Oxford 2001.

Nguyen N.L., Roman Rape: An Overview of Roman Rape Laws from the Republican Period to Justinian's Reign, Michigan Journal of Gender and Law 2006, vol. 13, no. 1.

Shaw B.D., Il bandito, in: L'uomo romano, ed. A. Giardina, Roma-Bari 1989.

Shaw B.D., Bandits in the Roman Empire, in: Studies in Ancient Greek and Roman Society, ed. R. Osborne, Cambridge 2004.

Sitek B., "Raptores virginum vel viduarum vel diaconissarum". Studio sul rapimento delle donne votate a Dio nelle costituzioni degli imperatori romani [online], Diritto@ Storia. Rivista Internazionale di Scienze Giuridiche e Tradizione Romana 2006, no. 5, http://www.dirittoestoria.it/5/Tradizione-Romana/Sitek-Raptores-virginum.htm [access: 29.06.2020].

Solazzi S., Furto di notte e desuetudine della legge, in: idem, Scritti di diritto romano, vol. 3, Napoli 1960.

The Theodosian Code and Novels, and the Sirmondian Constitutions. A Translation with Commentary, Glossary, and Bibliography by Clyde Pharr in Collaboration with Theresa Sherrer Davidson and Mary Brown Pharr, with an Introduction by C. Dickerman Williams, Princeton 1952 (reprint New Jersey 2001).

Wieacker F., Lateinische Kommentare zum Codex Theodosianus, in: Symbolae Friburgensis in honorem Ottonis Lenel, Leipzig 1931.

Wiewiorowski J., Odpowiedzialność senatora, który uprowadzit dziewice (pannę) uwagi na marginesie CTh 9.1.1. = C 3.24.1, in: Contra leges et bonos mores. Przestęstwa obyczajowe w starożytnej Grecji i Rzymie, ed. H. Kowalski, M. Kuryłowicz, Lublin 2005.

Wiewiorowski J., Porywanie kobiet jako zjawisko społeczne w późnym antyku. Moralność a prawo, in: Homo, qui sentit. Ból i przyjemność w średniowiecznej kulturze Wschodu i Zachodu, ed. J. Banaszkiewicz, K. Ilski, Poznań 2013.

\section{Sum mary}

The notion of self-defence was visible in Roman law even in the archaic period. First mention that can be recognised as such was the right to kill a thief referred to in the Law of Twelve Tables. The institution gradually developed, encompassing a growing range of cases. However, regulations were still mostly casuistic. That also applies to the legislation of Christian emperors.

Key words: self-defence, Christian emperors, latrones 


\section{OBRONA KONIECZNA W USTAWODAWSTWIE CESARZY CHRZEŚCIJAŃSKICH}

\section{Streszczenie}

Pojęcie obrony koniecznej było widoczne w prawie rzymskim już w okresie archaicznym. Pierwsza wzmianka dotycząca tej instytucji to regulacja Ustawy Dwunastu Tablic dopuszczająca zabicie złodzieja nocnego i dziennego, który broni się orężem. Instytucja stopniowo się rozwijała, obejmując coraz większą liczbę przypadków. Jednak regulacje były nadal w większości kazuistyczne. Dotyczy to również ustawodawstwa chrześcijańskich cesarzy.

Słowa kluczowe: obrona konieczna, cesarze chrześcijańscy, latrones

\section{ПРАВО НА НЕОБХОДИМУЮ ОБОРОНУ В ЗАКОНОДАТЕЛЬСТВЕ ХРИСТИАНСКИХ ИМПЕРАТОРОВ}

\section{Резюме}

Понятие необходимой обороны присутствовало в римском праве еще в архаический период. Первое упоминание об этой институции - это положение Закона о двенадцати таблицах, позволяющее убивать ночного и дневного вора, который защищает себя оружием. Институция постепенно развивалась, охватывая все большее число случаев. Тем не менее, правила все еще были в основном казуистическими. Это также относится к законодательству христианских императоров.

Ключевые слова: необходимая оборона, христианские императоры, latrones 